\title{
СТАТЕВЕ ВИХОВАННЯ ЯК ПЕДАГОГІЧНА ПРОБЛЕМА
}

\author{
Н. В. Попович \\ Міжгірський медичний коледж \\ ДВНЗ «Тернопільський державний медичний університет \\ імені І. Я. Горбачевського МОЗ Украӥни»
}

У статті проаналізовано роль статевого виховання як мету, яка грунтується на формуванні у молоді статевої етики, естетики та гігієни, культури інтимних відносин, любові та сімейного життя, наукових знань про фізіологічні особливості організму, морально-етичні норми і стосунки між особами протилежної статі та роль у цьому процесі сім’ї та педагогів.

\section{SEXUAL EDUCATION AS A PEDAGOGICAL PROBLEM}

\author{
N. V. Popovych \\ Mizhhirskyi Medical College \\ I. Horbachevsky Ternopil State Medical University
}

The article analyzes the role of sexual education as a goal based on the formation of sexual ethics in young adults, as well as aesthetics and hygiene, culture of sexual relationships, love and family life, the formation of scientific knowledge about the physiological peculiarities of the organism, moral and ethical norms and relations between persons of the opposite sex and role of family and teachers in this process.

Вступ. Статеве виховання - система медичних та педагогічних заходів, спрямованих на виховання у дітей, підлітків і молоді розумного, здорового ставлення до питань статі. Статеве виховання за змістом включає анатомо-фізіологічні особливості підлітків, формування відчуття статі, свого соціального призначення, виховання гігієни статі та статевого життя, інформування з питань захворювань і ушкоджень статевих органів, а також цілеспрямований, систематичний розвиток у дітей культури емоційних відносин між статями, волі, вміння керувати власними почуттями та вчинками. Мета статевого виховання стосується формування в молоді статевої етики, естетики та гігієни, культури інтимних відносин, любові та сімейного життя, наукових знань про фізіологічні особливості організму, морально-етичні норми і стосунки між особами протилежної статі.

Статеве виховання підлітків здійснюють за декількома основними напрямками: в процесі організації спілкування хлопчиків та дівчат з дитячих років, у змістовній праці та відпочинку, через етичне виховання в питаннях товариства, дружби, любові, в старшому віці; у питаннях статевої моралі, через опосередкова-

(c) Н. В. Попович, 2019 ний вплив сім'ї та ознайомлення старшокласників 3 основами підготовки до сімейного життя [7].

Культура статевого життя - частина культури суспільства. Безліч різноманітних обставин спричинили те, що психосексуальна культура виявилася досить низькою. Ситуація, що склалася, спричиняє виникнення проблем, які, у свою чергу, значно впливають на психіку, здоров'я і особисте щастя. Культура статевого життя залежить від сформованої статевої свідомості. Це вказує на те, що виникла необхідність розробки і формування сучасної етики з питань статі, яка увібрала би зразки і принципи поведінки в статевому житті, які спираються на сучасні знання в цій галузі. Вони повинні враховувати оптимальні біологічні, психологічні, соціальні та етичні характеристики, які можуть слугувати зразками для виховання. Соціалізація сексуальної поведінки проявляється в засвоєнні сексуальних і суспільних норм, в сексуальній культурі, яка зумовлена статевим та сексуальним вихованням, і в сексуальному досвіді. Поняття «культура» походить від лат. «culture», що означає виховання, освіта, розвиток. Вона відображає закономірності розвитку суспільства на тому чи іншому етапі та включає рівень освіченості, вихованості людей, а також рівень оволодіння 
ними якоюсь галуззю знань або діяльністю. Культура виступає як концентрований, організований досвід людства, основа розуміння, осмислення оточуючої дійсності, інтеграції будь-якої спільноти, реалізації потенцій людей. Будь-яка особистість виступає відносно культури в декількох іпостасях: як «продукт» культури, який засвоює їі норми, цінності, технології діяльності в процесі соціалізації; як «споживач» культури, який використовує її норми і правила, типові шляхи самоідентифікації та самореалізації в своїй соціальній практиці; як «виробник» культури, який творчо породжує нові форми культури; як «транслятор» культури, що передає інформацію про їі норми, цінності, зразки іншим людям. Говорячи про психосексуальну культуру, зазначимо, що вона є складовою загальної культури людини, передбачає формування такої поведінки, яка відповідає вимогам і нормам того суспільства, в якому формується особистість людини. Психосексуальна культура передається від покоління до покоління, формує масову й індивідуальну статеву свідомість. Шляхи цієї передачі позначаються терміном «статеве виховання», яке передбачає вплив суспільства на психосексуальний розвиток і становлення особистості людини. Значне місце в формуванні статевої свідомості належить освіті - знанням про статеві відмінності, фізіологію і психологію статі, психосексуальні процеси і стосунки. Формування статевої свідомості через виховання можна розглядати як прогресивні форми соціалізації особистості. Статеве виховання - складова загального процесу виховної роботи навчального закладу і сім'і, що забезпечує правильний статевий розвиток дітей і молоді [1].

Основна частина. Щоб з'ясувати, який рівень статевого виховання діти отримують в сім'і, як провели анкетування батьків учнів, за допомогою якого передбачалося встановити ступінь довіри при спілкуванні дітей з батьками на теми міжстатевих взаємин, рівень оволодіння знаннями з цих питань для передачі їх дитині, ставлення батьків до введення окремого курсу для здійснення статевого виховання підростаючого покоління тощо.

Анкетуванням було охоплено 94 родини. Аналіз анкет свідчить про те, що батьки фактично не займаються статевим вихованням своїх дітей, тільки $8 \%$ сімей із власної ініціативи змогли вміло і доступно подати своїм дітям інформацію щодо міжстатевих взаємин. Насамперед матері намагаються дати дочкам необхідні знання, остерігаючись за їхню долю (непланова вагітність). До того $ж$, саме матері більш відверті у питаннях міжстатевих взаємин із власними дітьми як з хлопчиками, так і з дівчатками. Батьки ж цими питаннями займаються дуже мало. Бесіди 3 питань статевого життя передбачають насамперед довіру. Причиною того, що діти не можуть розмовляти з батьками відверто на такі теми, $є$ ухиляння дорослих від відповідей або їх неправдивість. Це створює бар'єр у спілкуванні з дітьми. У багатьох батьків ще з молодих років склалося ставлення до обговорення питань статевого життя як до чогось неприпустимого. Батьки, які самі не отримали у своїх сім'ях відповідного виховання, не можуть (42 \%) або не вміють (58 \%) обговорювати ці питання. Як показало опитування, більшість із них (79 \%) не володіє знаннями з питань статевих взаємин, не має педагогічних здібностей у вирішенні цього питання з власними дітьми. Некомпетентність з цих питань і зумовлює неоднозначність у ставленні до них, тому більшість дітей отримала інформацію про міжстатеві взаємини не від батьків, а з інших джерел.

Про те, чи вперше дитина отримала інформацію сексуального характеру саме від батьків, більшість дорослих (62 \%) відповіли, що «ні», мотивуючи тим, що не помітили, як їхня дитина подорослішала, інші розраховували на допомогу книжок, які вони непомітно «підкладали» дітям. Третя група побоювалася ознайомлювати дітей з таємницями сексу через страх, що такі питання «розбудять» інтерес і навіть надмірну активність. 26 \% сімей не впевнені в тому, що діти вперше отримали таку інформацію саме від них, оскільки оточення (друзі, знайомі, вулиця), в якому постійно перебуває дитина, могло вплинути та поінформувати з цих питань раніше за них. Крім того, батьки не впевнені в авторитетності джерел інформації з цих питань, об'єктивності та відповідності інформації віковим можливостям дитини.

І лише 12 \% родин дали ствердну відповідь. Вони вважають, що неприпустиме замовчування та покарання дітей за «непристойні» запитання. Упевнені, що ті діти, з якими вдома батьки відверто розмовляли на теми міжстатевих взаємин, мають моральний імунітет проти «освіти» вулиці або інших джерел інформації.

Для статевого виховання дуже важливо як батьки прореагували на цікавість дитини щодо статевих взаємин та як відповіли на запитання з цих тем. Можна припустити, що діти, батьки яких дали на їхні запитання ухильну відповідь (59 \%) або сказали неправду (37 \%), надалі відмовляться від допомоги батьків із цих питань. 
Анкетування виявило і те, що 58 \% опитаних відповіли негативно на запитання, чи хотіли 6 вони, щоб діти створили майбутню сім'ю на зразок їхньої, $27 \%$ - не впевнені та 15 \% дали позитивну відповідь. Це свідчить про те, що сім'я не завжди є взірцем міжстатевих взаємин дорослих. Причиною таких відповідей батьків $\epsilon$ те, що більшість із них розлучилися (неповні сім'i), одружені вдруге, мають внутрішньосімейні конфлікти через матеріальний стан родини, психологічну несумісність та небажання знаходити компроміс у ситуаціях, що виникають, байдужість один до одного, що, у свою чергу, відображається на соціальній адаптації дитини і виникненні труднощів в особистому житті та статево-рольовому формуванні.

Майже всі батьки (97 \%) висловили бажання, щоб був введений курс для статевого виховання підлітків. Вони переконані, що це дало б бажаний позитивний результат, оскільки коледж протягом тривалого періоду значною мірою впливає на формування свідомості, поведінки вихованців. Крім того, батьки побажали, щоб статевою освітою та вихованням їхніх дітей займалася спеціально підготовлена людина, компетентна у цих питаннях, із педагогіко-методичними вміннями вирішення завдань зі сфери міжстатевих взаємин.

Складається враження, що батьки, даючи позитивну відповідь на це запитання, ніби намагаються перекласти частину своїх обов'язків щодо статевого виховання на педагогів, забуваючи про те, що насамперед вони відповідальні за виховання власних дітей. Хоча $\epsilon$ і такі батьки, які хотіли, щоб школа, ввівши такий курс для підлітків, допомогла 6 їм залучитися до питань формування статевої культури у їхніх дітей.

Висновки. Прикро, що не всі батьки статеву освіту в сім'і розглядають як основний елемент статевої вихованості, незважаючи на те, що сімейне виховання має важливе значення у вихованні високоморальної людини, у її підготовці до дорослого самостійного життя.

На жаль, не всі батьки розуміють, що особливе значення при статевому вихованні належить родині, що батьки є взірцем для своїх дітей.

Батьки повинні пам'ятати, що найважливішими завданнями сім'ї у формуванні статевої культури $€$ виховання жіночності та мужності, виховання поваги до іншої статі, підготовка до виконання численних подружніх обов'язків у майбутній власній родині [6].

Однак, більшість батьків через власну неосвіченість або ігнорують цей аспект виховання, або навмисно, часом з удаваної сором'язливості, намагаються уникати розмов на інтимні теми. Такий підхід $\epsilon$ не тільки хибним, а навіть небезпечним, адже у підлітковому віці виникає багато проблем, серед яких проблеми, пов'язані зі статевим дозріванням, часто набувають першочергового значення. Дорослі хочуть, щоб їхні діти отримали освіту з питань статевої поведінки, але соромляться обговорювати їх з власними дітьми. Проте тема інтимних стосунків між підлітками і роль сім'ї у цей відповідальний момент у житті їхніх дітей - особлива і відповідальна, оскільки підлітки дуже вразливі, негативно реагують на втручання в особисте життя. До того ж, більшість батьків не володіє інформацією щодо обізнаності власних синів і дочок з питань інтимних стосунків [5].

Статеве виховання - це складова виховного процесу, комплекс способів, засобів та форм, що забезпечують правильний статевий розвиток, здорове ставлення до питань статі та формування соціально схваленої статевої поведінки особистості; метою статевого виховання $є$ формування у підростаючого покоління гігієни, етики та культури статевих відносин [3]. Як і кожен напрям виховання, статеве виховання ґрунтується на загальних принципах виховного процесу та використовує загальновиховні методи, засоби і форми. Зміст статевого виховання умовно «стоїть на трьох китах»: 1) знання про фізіологію статі; 2) виховання гігієни статі та статевого життя; 3) формування «відчуття» статі, соціальна стать [2]. Статеве виховання - напрям виховання, який, у тій чи іншій формі здійснюється в будь-якій національній системі освіти, а зміст статевого виховання в тій чи іншій країні - своєрідний індикатор існуючих там соціальних проблем. І відповідно до цих проблем та інших, не менш важливих чинників (релігійність, рівень моральної культури тощо), формується концепція статевого виховання [4].

2. Трутнев И. А. О семье, браке / И. А. Трутнев, Н. М. Ходаков. - М. : Медицина, 1969. - 140 с.

3. Комарова А. І. Статеве виховання і моральна культура молоді / А. І. Комарова. - К. : Товариство «Знання», 1982. 
4. Шикирава Н. Формування статевої моралі учнівської молоді / Н. Шикирава // Психолог. - 2004. - № 23-24. С. $45-48$.

5. Шнейдер Л. Б. Психология семейных отношений : курс лекций / Л. Б. Шнейдер. - М. : Апрель-Пресс, ЭКСМОПРЕСС, 2000. - 512 c.
6. Сухомлинський В. О. Вибрані твори у 5-ти томах / В. О. Сухомлинський. - К. : Радянська школа, 1979. - Т. 5.

7. Ильин Е. П. Дифференциальная психофизиология мужчины и женщины / Е. П. Ильин. - СПб. : Петербург, 2006.

Отримано 05.02.19 